\title{
PATIENT-RESPONSE TO HOSPITALISATION
}

\author{
Maureen Salmon, M.B., B.Ch. (Rand)., \\ Medical Director, Lederle Laboratories, Johannesburg
}

(Formerly Medical Superintendent, Johannesburg and Boksburg-Benoni Hospitals)

\section{OPSOMMING}

Die moderne nukleêre en nywerheidsamelewing is as gevolg van druk wat op hom geoefen is, gedwing om hospitalisasie as ' $n$ integrerende deel van die samelewing te aanvaar. Die koms van mediese en siekefondse het die ontwikkeling aangemoedig. As ons, behalwe bekwame mediese en verpleegsorg - met inagneming van die kultuuromgewing waaruit die pasiënt kom - persoonlike pasiëntesorg kan byvoeg, sal ons ver gevorder het om die siekes van die land tot aanvaarding van hospitalisasie aan te moedig.

$\mathbf{S}^{\mathrm{n}}$ NCE that fateful moment in the Garden of Eden when our ancestor Adam was tempted to eat of the forbidden fruit, illness and disease entered man's existence. Primitive civilizations regarded disease as of supernatural origin and in the Middle Ages illness was interpreted as a manifestation of the will of God. With the evolution of modern medicine, hospitals have ceased to be primarily charitable institutions or refuges for the homeless and have become highly complex organisms directed at the highest possible standard of patient care. It is sad that in this striving towards maximal therapeutic efficiency, the understanding of the patient as a total person tends to suffer.

$\mathrm{Coe}^{1}$ sees a hospital as a "place where members of a community can obtain services designed to restore them to good health, a place for rehabilitation of the physically disabled and a setting in which especially older members of the community can obtain services to restore partially the use of enfeebled limbs, or vital organs worn with age"'.

Virginia Henderson ${ }^{2}$ is more caustic when she says that a hospital is too often " a setting where shelter from the elements is almost the only fundamental need that is fully met",

To be suddenly and summarily removed from the security of his home to the strange, impersonal and frightening environment of a hospital can be a traumatic experience for a patient. At home, even when ill, he retains his identity, surrounded by his family and friends. In hospital, "the patient is an enforced member of a group living in an entirely artificial environment, bearing no relation to anything approaching ordinary home life." Illness is an intensely personal matter, calling for support from family and friends. Not only is the patient in hospital deprived of this comfort, but in addition he is exposed to a series of interactions with strangers. There is complete lack of privacy and he is expected to allow strangers, including members of the opposite sex, to view and handle his body. In the words of Jules Henry " "when stripped of clothing, jewelry and other symbols of identification, the patient's perception of himself as a person must undergo considerable deterioration - a social process of dehumanisation and depersonalisation."

Small wonder then, that many patients have a dread of hospitalisation. In order to understand a patient's response to hospitalisation, we have first to understand his cultural and social background. The mores, norms, attitudes and values of which he has been an integral part must surely influence his adaptation to the sick role, and affect his reaction to, and behaviour in, the hospital setting.

In our multiracial country we are uniquely privileged in being able to observe at first hand the cultural differences in the attitudes towards illness and hospitalisation of our various ethnic groups.

It seems then that if the illness is serious, the White patient receives the support of society and is encouraged to seek early hospitalisation, particularly if he belongs to the upper classes. Members of the lower classes respond more relucantly to the need for hospitalisation. The economic stresses of our modern way of life require wives to work, thus precluding the nursing of seriously ill persons at home. Fortunately the ever-improving standard of medical and nursing care must encourage 
the ailing White patient to accept hospitalisation. On the other hand, we must remember that stigma attaches to certain diseases such as venereal disease, mental ilIness and even tuberculosis. This may make a patient reluctant to seek medical help, and subsequent hospitalisation may then engender embarrassment and guilt feelings as the patient's response.

As for our Black population, Gumede ${ }^{4}$ underlines the fact that Africans do not recognise the "germ theory" of disease, and that traditional African cultural practices continue to offer strong barriers to improved health services. Mgobozi ${ }^{5}$ states that to the African all disease is unnatural, and deeprooted superstitions persist that the disease is caused by witchcraft or other human agents. He states that the majority of African people make use of the White man's medical services and are grateful for the relief of pain, but do not believe that the treatment influences the fundamental cause of illness. The difference in the attitudes to disease may perhaps be summarised by saying that the White man asks "what caused the disease?" whilst the African poses the question "who caused the disease?" This is particularly so amongst rural Africans. In his plea for help to the witchdoctor, hospitalisation plays no part. $\mathrm{He}$ is therefore not culturally prepared for hospitalisation so his response is negative. Other factors, too, influence his reluctance to be hospitalised. His home, his family, his belongings and his job may well be at risk for the period he is in hospital, and who will earn money to support his wife and children? He therefore tends to seek hospitalisation late, and his response is one of scepticism, mistrust, suspicion and apprehension.

Similarly the Indian community's response to hospitalisation is coloured by its cultural background. It is a fact that tuberculosis carries profound stigma amongst Indians, together with a strong element of personal guilt. To the Hindu it is a secret and shameful illness. Furthermore, imagine the response of the strict Hindu patient who finds he is sharing ward accommodation and facilities with a Moslem.

Having shown that the patient's response to hospitalisation may well be influenced by sociological pressures prior to admission, let us now attempt to empathise with a hypothetical patient presenting at hospital for admission. Having been subjected to the profound anxiety of sudden illness he leaves the security and seclusion of his home environment and is transported to hospital in a bumpy ambulance peopled with strangers who handle him as impersonally as a log of wood.

Arriving at hospital, he is interrogated by a stranger who asks personal (and, he feels, unnecessary) questions regarding his financial status, the size of his family, etc. Other strangers of the opposite sex undress him and urge him to use a bedpan. Still others listen to his chest and prod his abdomen whilst satisfying themselves he requires admission. Not infrequently the nightmare situation is aggravated by young persons in white coats, with stethoscopes prominently displayed, who gather round and discuss in penetrating voices his symptoms, diagnosis and treatment. Can he be blamed if at this stage his response to hospitalisation is apprehensive and antagonistic.

Having been pushed on a trolley down long, winding corridors, in and out of lifts, he finally arrives at his destination - the ward - a frightening place of strange sights, sounds and smells. Here he is divested of his garments and valuables and ensconced in a high, uncomfortable bed, probably surrounded by twenty or thirty equally unhappy patients. From this moment until the day of his discharge (if he survives) he has to accustom himself to a new world - a strange world of ceaseless activity, constant comings and goings, bright lights, strange noises, hospital odours, queer food, frightening apparatus and a total lack of privacy. He must submit to being the subject of medical procedures carried out by a variety of people - doctors, nurses, physiotherapists, etc.

For the first time in his adult life he finds himself totally dependant on other people for all his needs. $\mathrm{He}$ becomes a "passive recipient" - the case in bed 16, expected to co-operate at all times with those in command. Non-compliance brands him as a "difficult patient".

His identity has been lost and his total concentration centres around himself, his body, his illness, the pain he has to bear, the tests and treatment he has to undergo, and finally (and fearfully!) the prognosis. Is death perhaps touching his elbow? He longs to question his doctor but is afraid to do so. His whole existence shrinks and narrows to the confines of his hospital bed. The scope of his world is narrowed and he is apathetic to all but his own fear and misery.

Belief of disfigurement or death may influence a patient to refuse treatment, e.g. amputation of a limb. He may even deny illness because of expense or the fear of death.

When the acute phase of his illness is over, much of the intensive medical and nursing care is withdrawn and the patient is expected to largely fend for himself, and not be dependant. Convalescence is regarded as a testing time to relearn to be an adult. Is it surprising then that at this point his response is likely to be one of rejection, frustration and peevishness.

The above description of the patient's response to hospitalisation is obviously extreme, but that there is a grain of truth in it is borne out by well-known authors. Virginia Henderson" states "In most hospitals the patient cannot eat as he wishes; his freedom of movement is curtailed; his privacy is invaded; he is put to bed in strange nightclothes that make him feel as unattractive as a punished child; he is separated from the objects of his affection; he is deprived of almost every diversion in his normal day, deprived of work and reduced to dependence on persons often younger than he is and sometimes less intelligent and courteous"... . 
Ek wil nou aan u 'n vraag stel -

Waarvan hou pasiënte die minste wanneer dit kom by hospitalisasie?

By 'n kliniese vergadering wat onlangs gehou was by een van ons akademiese hospitale was die volgende punte uitgelig:

(1) Verlies van identiteit.

(2) Onpersoonlike benadering deur die personeel.

(3) Verlies aan ondersteuning van sy gesin en naasbestaandes.

(4) Beperking van besoekure/of ondoeltreffende beheer van besoekers.

(5) Die mens se liggaam wat deur vreemdelinge hanteer word - en privaatheid - dit bestaan nie.

(6) Totale afhanklikheid op andere.

(7) Geraas.

(8) Eentonige smaaklose voedsel.

(9) Onrealistiese ure - nog voor dagbreek wakker gemaak.

(10) Slaap wat versteur word - aktiwiteite in die afdeling.

(11) Nie genoegsame "stilpouses" gedurende die dag nie.

(12) Onbedagsame en taktlose gedrag van sommige van die personeel.

(13) Gebrekkige kommunikasie - personeel te besig om te praat.

(14) Doktors wat versuim om die diagnose, behandeling of prognose met die persoon te bespreek.

(15) Geestelike behoeftes word nie altyd in voorsien nie.

(16) Gebrek aan sindelikheid in hospitale.

(17) Verontwaardigheid van die pasiënt byvoorbeeld verwydering van kunstande voor operasies.

(18) Bekommernis oor ekonomiese en huishoudelike probleme.

(19) Dat hy as mens as 'n opleidingsmeganisme gebruik word.

(20) Besoekers wat jou laat voel asof jy nie meer deel uitmaak van die sogenaamde buite normale wêreld nie.

(21) Maar veral wil ek die volgende noem:

Vrees vir pyn

Vrees vir verminking

Vrees vir ongeskiktheid

Vrees vir die toekoms

Vrees vir die DOOD.

As gevolg van die tekort aan hospitaalbeddens, word die toelating van die ernstige siek of beseerde pasiënt beperk. Dus volg dit dat die mortaliteits-indeks in hospitale relatief hoog is. Dit is dus denkbaar dat sterftesyfers 'n prominente rol speel in die gedagtes van die sieke. Soos Peter Pan, glo alle mense dat hulle vir ewig sal lewe. Die dood - dit tref ander mense, ander gesinne. Wanneer die mens met die dreigement van die dood gekonfronteer word - word alle ander dinge gering en onbelangrik. Rykdom en mag verloor hulle betekenis en waarde. Waaneer die dood in die oë gestaar word - word alle mense gelyk . . .

Van den Berg ${ }^{7}$ tells us that death is the quality of life, the index of value of human existence. He feels patients should be encouraged to talk about death. "To deny a person the right to contemplate approaching death means denying him the right to see his life as a whole". I ack of opportunity to talk to an understanding person leads to frustration.

What is society doing to break down the negativism of the patient vis-à-vis hospitalisation? To-day the emphasis at medical schools is on preventive medicine and community medicine. In the past the curriculum concentrated on the pathology of physical disease. Now the importance has been realised of the "total concept" of patient care - physical, psychological and sociological. Concurrently, health education of the masses is being undertaken and it is hoped that under its impact, old cultural prejudices will disappear.

Similarly in planning new hospitals, considerable thought has been given to the welfare of the patient. The patient is the V.I.P. in our planning programme. We have learned from the mistakes of the past. For instance, the large wards of hospitals will be superseded by smaller wards with improved toilet facilities, thus ensuring comfort and privacy. Similarly the use of frozen foodstuffs will allow patients a choice of tasty meals. Visiting hours have been extended and special privileges are accorded to near relatives of seriously ill patients. Constant efforts by management are directed at encouraging courtesy, friendliness and warmth on the part of all staff.

Our modern nuclear and industrial society has been forced as a result of the social pressures exerted upon it, to accept hospitalisation as an integral part of society. The advent of medical and benefit societies has encouraged this development. If, in addition to skilled medical and nursing care, we can add personalised patient care, remembering the cultural milieu from which the patient originates, we will have gone a long way towards encouraging acceptance of hospitalisation by the sick of our country.

\section{BIBLLOGRAPHY}

1. Coe, R.M. Snciology of Medicine, McGraw-Hill Inc., U.S.A. 1970, pp. 233-243.

2. Henderson, Virginia. The Nalure of Nursing. Collier, McMillan Lid, London, 1966 pll.

3. Henry, I. Culture ggainsı Man, Random House, New York, 1963, p.391

4. Gumede. M.V. Tradition and Customs. The Leech. Vol 44, No. 2, 1974, Johannesburg p.35.

5. Mgobozi, P. M. The Prohlem nf Tuberculnsis amang Africans, The Leech, Vol 44, No. 2 1974, Johannesburg, p.45. 1974, Johannesburg, p.45.
Henderson, Virginia. Op. Cit.

6. Henderson, Virginia. Op. Cit.
7. Van den Berg. The Psychalogy of the Sickhed, Duquesne University Press, Pitrsburgh, 1966, pp. 54 and 55. 